\title{
PIRANTI KOMPUTASIONAL SYSTEMIC CODER SEBAGAI ALAT BANTU ANALISIS TEKS BERBASIS SYSTEMIC FUNCTIONAL GRAMMAR
}

oleh Pangesti Wiedarti

FBS Universitas Negeri Yogyakarta

\begin{abstract}
This article first presents the Systemic Functional Grammar (SFG), developed by Halliday $(1985,1994)$ and Halliday and Matthiessen (2003), one grammar that can be used in language analysis. Then it describes briefly the use of the Systemic Coder (SC), a computational tool developed by O'Donnell (1994) that is especially beneficial for linguists to employ in language analysis based on SFG when they have to deal with huge corpora and need quick results as it facilitates getting comprehensive data characteristics in a relatively short time. SC is applicable in Indonesia as its platform is the commonly used MSWord and it can be utilized in analyzing any language employing the Latin alphabet. There are other advantages of SC application, which understandably requires, among others, one's mastery of SFG.
\end{abstract}

Keywords: systemic functional grammar, systemic coder, language analysis

\section{A. Pendahuluan}

Tulisan ini membahas piranti komputasional systemic coder (berikutnya disingkat SC, http://www.wagsoft.com/software.html) yang dikembangkan oleh O'Donnell berdasarkan teori systemic functional grammar (disingkat SFG, Halliday 1985, 1994). SC yang berbasis SFG sejauh ini belum banyak diterapkan di Indonesia.

Pemakaian bahasa (terwujud dalam bentuk teks lisan atau tulis) sesuai Tatar komunikasi dapat dianalisis berdasarkan kerangka analisis SFG yang menghasilkan karakteristik masing-masing teks dan sisi leksikon dan gramatika. Dengan kebermanfaatannya itu, SFG selain diterapkan di Australia, juga diterapkan di Jepang (Japan Association of Systemic Functional Linguistics), Asia Tenggara, Amerika Utara, 
Amerika Selatan, Eropa dan UK (info rinci dapat dilihat pada http:// www.wagsoft. com/Systemics) dengan kajian berbagai bahasa.

SC dipilih sebagai piranti dalam analisis bahasa karena SC mempunyai keunggulan: (a) berplatform msword; (b) juga dapat dipakai untuk menganalisis korpus teks dari dimensi teori Appraisal System, (c) penerapannya relatif lebih mudah dibandingkan piranti komputasional lainnya yang juga berbasis SFG karena panduannya jelas dan komprehensif, dan (d) SC dapat diaplikasikan bagi alat bantu analisis berbagai bahasa sejauh bahasa tersebut menggunakan abjad Latin abc.

Karena SC merupakan alat bantu analisis korpus teks, penerapannya hams didahului dengan pemahaman terhadap SFG. Beberapa kegiatan analisis harus dilakukan secara manual sebab SC tidak diaplikasikan sepenuhnya otomatis seperti halnya Concordance dan TransTool. Camper tangan manusia tidak dapat dihindarkan karena penganalisisan bahasa memerlukan sense tersendiri selain penguasaan terhadap teori SFG. Setelah SFG dipaparkan secara teknis dipaparkan bagaimana SC dioperasikan.

\section{B. Systemic Functional Grammar}

Penegasan pendekatan terhadap bahasa perlu sedikit dibahas karena berkaitan dengan kerangka analisis kebahasaan. Pada hakikatnya, terdapat dua golongan besar pendekatan yaitu dari sudut pandang (a) filosofis-logis yang mengaitkan bahasa dengan filsafat, beranggapan gramatika merupakan bagian dari logika; dan (b) deskriptif-etnografis yang mengaitkan bahasa dengan antropologi, beranggapan gramatika merupakan bagian dari (ke)budaya(an).

Berkaitan dengan kedua pendekatan di atas, Sutjaja (1989) memaparkan madhab filosofis-logis memandang bahasa sebagai kaidah (rule) sedangkan madhab deskriptif-etnografis memandang bahasa sebagai sumber (resource). Walau terjadi perbedaan cara memandang bahasa, keduanya memberi perhatian besar pada aspek sistem, yaitu keterkaitan antara sistem dan perilaku. Linguis yang termasuk dalam madhab filosofis-logis adalah Chotnky dengan bukunya Syntactic

DIKSI Vol.12, No.2, Juli 2005 
Structures (1957) dan Aspects of the Theory of Syntax (1965). Linguis yang menonjol dalam madhab deskriptif-etnografis adalah Halliday dengan bukunya Introduction to Functional Grammar (merupakan perkembangan teori Skala dan Kategori dan teori Ketransitifan dalam bahasa Inggris) (Halliday, 1974, 1978, 1985, 1994; Halliday \& Matthiessen, 2003). Karena Halliday menganggap bahasa sebagai resources, konsekuensinya, tidak perlu pembedaan secara tajam antara unsur "competence" dan "performance" seperti halnya pendekatan filosofis-logis menekankannya. Dengan kata lain, bagi Halliday, hal terpenting dalam berbahasa adalah kebermaknaan (meaningfulness) dan penerapan praktis dari bahasa itu.

Lebih lanjut Halliday (1994: xxvii) menjelaskan SFG bersifat deskriptif, pendekatan lebih ke arah linguistik terapan daripada linguistik murni, bersifat retoris daripada logis, bersifat aktual daripada ideal, bersifat fungsional daripada formal, menekankan pada teks daripada kalimat, menekankan analisis teks sebagai tindakan, dan teori bahasa diartikan sebagai alat untuk menyelesaikan sesuatu hal.

Tulisan ini, lebih mengacu kepada pandangan Halliday sebab bahasa tak bisa dipungkiri merupakan atribut sentral dari manusia yang mahluk sosial, yang menggunakan bahasa sebagai alat berinteraksi pada situasi sosial tertentu. Cara pandang tersebut kini diterapkan dalam pengajaran bahasa di sekolah menengah (khususnya pengajaran Bahasa Inggris yang diarahkan kepada pendekatan genre) berdasarkan Kurikulum Berbasis Kompetensi (http://www.puskur.or.id) yang menekankan pada aspek kecakapan berbahasa untuk menunjang life skills yang harus dimiliki siswa.

\section{Model Bahasa dalam Systemic Functional Linguistics}

Halliday (1978) memandang bahasa sebagai sistem semiotik sosial, di dalamnya terdapat tiga aspek penting yaitu konteks, teks, dan sistem bahasa. Hubungan ketiganya dapat digambarkan pada Gambar 1. Gambar ini menggambarkan wujud bahasa umumnya berupa teks, terlisan maupun tertulis (dengan karakteristik masing-masing) yang 
berkaitan dengan konteks situasi. Konteks situasi ini mempengaruhi dan menentukan pilihan-pilihan bahasa (resources) yang dibuat seseorang ketika dia mengkreasikan dan menafsirkan teks. Dalam konteks apapun, seseorang menggunakan bahasa berdasarkan tiga fungsi utama (metafunction), yaitu ideational metafunction, interpersonal metafunction, dan textual metafunction. Ideational metafunction merupakan fungsi bahasa untuk mengkonstruksi atau mengemukakan gagasan atau informasi. Interpersonal metafunction merupakan fungsi bahasa untuk berinteraksi satu sama lain. Textual metafunction merupakan fungsi bahasa yang berkaitan dengan pengaturan bahasa atau teks dalam hal penataan hubungan unsur klausa, kalimat, dan paragraf agar pesan yang disampaikan mudah dipahami.

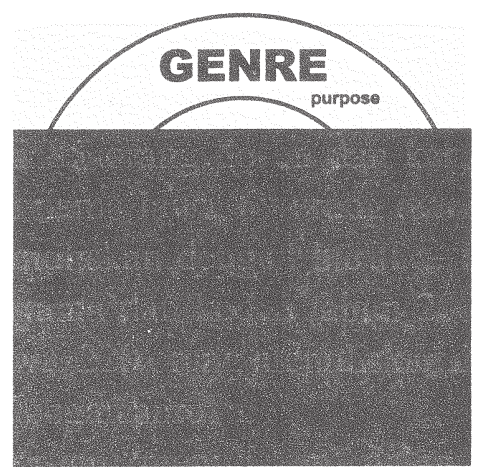

Gambar 1: The relationship of genre, register and language as text (Callaghan \& Rhothery 1993)

Konteks situasi yang mempengaruhi pilihan bahasa seseorang diwarnai tiga faktor, yaitu Field (topik yang dibicarakan), Tenor (hubungan interpersonal interlokutor) dan Mode (jalur komunikasi: terlisan/tertulis yang digunakan untuk berkomunikasi). Ketiga faktor ini yang menentukan interlokutor memilih pemakaian bahasa formal atau informal. Pemilihan bahasa oleh interlokutor ini tidak terlepas dan pilihan leksikon dan gramatika. (Genre dalam Gambar 1 tidak dibicarakan di 
sini karena ia merupakan teori tersendiri yang memerlukan pembahasan rinci).

Dalam SFG, istilah yang digunakan untuk tingkatan analisis bahasa (atau disebut 'strata') adalah semantik, grammar (termasuk sintaksis dan kosakata yang disebut leksikogramatika karena keduanya berada pada lingkup yang sama), dan fonologi. Sementara itu, Martin (1996) menyatakan "a language is interpreted as a system of meanings, accompanied by forms through which the meanings can be realised". Karenanya, suatu bahasa dianalisis dengan merujuk kepada empat strata, yaitu konteks, semantik (dalam konteks ini muncul istilah pragmatik), leksikogramatika, dan fonologi-grafologi. Keempat strata ini diorganisasikan secara hirarki dalam suatu sistem jaringan (network system).

Dalam analisis bahasa, SFG menekankan klausa sebagai unit terkecil seperti disampaikan Halliday (1982) dalam artikelnya "How is a text like a clause" sebagai berikut:

"Grammatically, that is where the action is; and within that, the fundamental unit of organization is the clause. It should be remembered that in functional grammar (where the terminology is on the whole more consistent), a clause is the same unit whether it is functioning alone (as a simple sentence) or as part of a clause complex (a compound/complex sentence).

Dalam praktik analisis bahasa, suatu teks (lisan atau tulis) wacana dipilah dalam paragraf-paragraf, dari paragraf dipilah menjadi kalimat-kalimat, dan dan kalimat dipilah menjadi klausa-klausa. Klausaklausa inilah yang menjadi objek penelitian yang ditinjau perilakunya berdasarkan SFG.

Klausa-klausa tersebut terstruktur fungsinya dalam bentuk tingkatan klausa (Halliday 1994; Matthiessen 1996; Martin, Matthiessen \& Painter 1997) yang diorganisasikan dalam dua sistem, yaitu TAXIS dan LOGICO-SEMANTIC. TAXIS berkaitan dengan hubungan 
interdependensi antara unit pembentuk klausa kompleks (Martin, Matthiessen \& Painter 1997:167). Hubungan ini terdiri dan dua macam yaitu HYPOTAXIS dan PARATAXIS. HYPOTAXIS merupakan istilah umum bagi hubungan klausa yang tidak setara di mana sebuah klausa mempunyai peran dominan ('the modified) dan klausa lainnya (satu atau lebih klausa) sebagai klausa terikat ('the modifying) (Martin, Matthiessen \& Painter 1997). Dalam analisisnya, klausa yang dominan diberi notasi abjad Yunani $\alpha$, sedangkan klausa terikat diberi notasi $\beta$, $\gamma$, dst. Contoh:

\begin{tabular}{|l|r|l|}
\hline P5.A13a. & $\alpha$ & Now, I wonder \\
\hline P5.A13b. & $\mathrm{x} \beta$ & if you'd feel the same way \\
\hline P5.A13c. & $\mathrm{x} \gamma$ & if you were dating a guy [[who had another male lover]]. \\
\hline
\end{tabular}

Istilah yang digunakan untuk menunjukan hubungan setara disebut PARATAXIS, di mana suatu klausa mengawali ujaran sedangkan klausa lainnya mengikutinya. Notasi yang diberikan adalah angka 123. Contoh:

\begin{tabular}{|c|c|c|}
\hline P9.A8a. & 1 & Developing his skill will boost his self-esteem, \\
\hline P9.A8b. & +21 & $\begin{array}{l}\text { and encouraging his enjoyment of it with others of a like } \\
\text { mind will expand his social circle }\end{array}$ \\
\hline P9.A8c. & +2 & $\begin{array}{l}\text { and give him the chance into practice [[getting on with } \\
\text { other people in an non-threatening setting]]. }\end{array}$ \\
\hline
\end{tabular}

LOGICO-SEMANTIC berkaitan dengan hubungan klausa, yang pada umumnya terdiri dan dua jenis yaitu EXPANSION dan PROJECTION (Halliday, 1994:219-273; Martin 1992:170-270; Matthiessen 1996; Martin, Matthiessen \& Painter 1997:170-173). Dalam EXPANSION klausa primer diperluas oleh klausa sekunder dengan cara "elaboration" (ditandai [ = ] 'setara'), "extending" (ditandai [ + ] 'ditambah'), dan "enhancing” (ditandai [ x ] 'dikalikan') (Halliday 1994:219). Dalam PROJECTION, klausa sekunder diprojeksikan pada klausa primer, yang menyatakan (a) lokusi (ditandai dengan [ "] tanda petik ganda; atau (b) gagasan ( [ ' ] tanda petik tunggal). Contoh: 


\begin{tabular}{|c|r|l|}
\hline P3.Q3a. & \multicolumn{1}{|c|}{$\alpha$} & Alittle over a month ago, he called me \\
\hline P3.Q3b. & $\mathbf{x} \beta 1$ & to tell me \\
\hline P3.Q3c. & "2 1 & he was leaving the area \\
\hline P3.Q3d. & $+2 \alpha$ & and (he) may never return \\
\hline P3.Q3e. & $\mathbf{x} \beta \alpha$ & because he learned \\
\hline P3.Q3f. & $1 \beta$ & he is HIV + \\
\hline
\end{tabular}

Selain struktur tingkatan klausa di atas, dalam SFG makna memegang peran penting. O'Donnell (http://www.wagsoft.com/ Systemics/Definition/definition.html) memaparkan bahwa sistemik semantik dibagi dalam tiga komponen yaitu semantik ideasional (berkaitan dengan isi); semantik interpersonal (berkaitan dengan fungsi pembicaraan, struktur percakapan, ekspresi sikap, dll.); semantik tekstual (bagaimana teks diorganisasikan sebagai suatu pesan, misalnya struktur theme, given/new, , struktur retorika, dll). Berikutnya, jaringan SFG diorganisasikan oleh "metafunction" dan strata seperti pada Tabel 1: The network of SFG

Tabel 1: The network of SFG

\begin{tabular}{|l|l|l|l|l|l|}
\hline $\begin{array}{l}\text { Generalised semiotic } \\
\text { function }\end{array}$ & Metafunctions & $\begin{array}{l}\text { Corresponding } \\
\text { Status of clause }\end{array}$ & $\begin{array}{l}\text { Lexico- } \\
\text { grammatical } \\
\text { patterns }\end{array}$ & Semantic & Register \\
\hline $\begin{array}{l}\text { LANGUAGE FOR } \\
\text { CONSTRUING } \\
\text { EXPERIENCE } \\
\text { as if'natural' reality }\end{array}$ & Ideational & $\begin{array}{l}\text { Clause as } \\
\text { representation }\end{array}$ & $\begin{array}{l}\text { Transitivity } \\
\text { (case) } \\
\text { Logical- } \\
\text { semantic } \\
\text { relations } \\
\text { (taxis) }\end{array}$ & $\begin{array}{l}\text {-Lexical } \\
\text { cohesion } \\
\text {-Conjunctive } \\
\text { relations }\end{array}$ & Field \\
\hline $\begin{array}{l}\text { LANGUAGEFOR } \\
\text { SONSTRUING THE } \\
\text { as intersubjective } \\
\text { reality }\end{array}$ & Interpersonal & $\begin{array}{l}\text { Clause } \\
\text { as exchange }\end{array}$ & $\begin{array}{l}\text { Mood, } \\
\text { modality } \\
\text { vocation, }\end{array}$ & $\begin{array}{l}\text {-Speech } \\
\text { function } \\
\text {-Exchange } \\
\text { structure }\end{array}$ & Tenor \\
\hline $\begin{array}{l}\text { LANGUAGE FOR } \\
\text { ORGANISING TEXT/ } \\
\text { PROCESING } \\
\text { as semiotic reality }\end{array}$ & Textual & $\begin{array}{l}\text { Clause as } \\
\text { message }\end{array}$ & $\begin{array}{l}\text { Theme } \\
\text { Information } \\
\text { structure } \\
\text { Nominalisation }\end{array}$ & $\begin{array}{l}\text { Reference } \\
\text { (participan } \\
\text { tracking) }\end{array}$ & Mode \\
\hline
\end{tabular}


“Clause as representation” merefleksikan gambaran mental suatu realita; memainkan peranan penting dalam prinsip umum untuk mewujudkan pengalaman dalam sistem tatabahasa dan variasi urutan kejadian, yang disebut TRANSITIVITY (Halliday 1994:106).

TRANSITIVITY ini menguraikan pengalaman pembicara/ penulis ke seperangkat PROCESS TYPES seperti yang digambarkan pada Gambar 2, sebagai berikut.

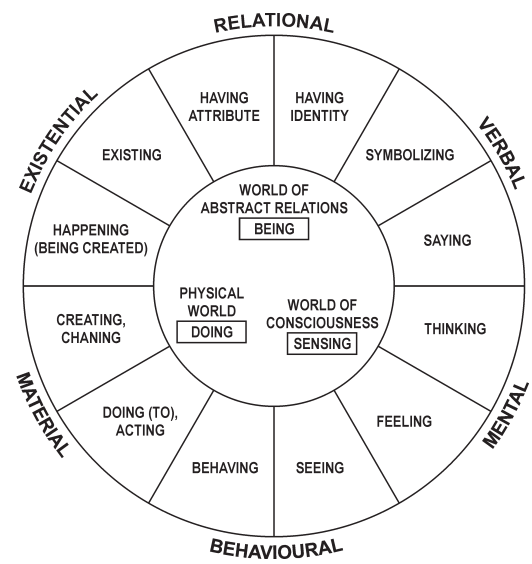

Gambar 2: The grammar of experience: Types of process in English (Halliday 1994:108)

Gambar 2 menunjukkan bahwa bahasa yang direpresentasikan dalam serangkaian klausa, berisi tiga refleksi yaitu "being (world of abstract relations)", "doing (physical world)" dan "sensing (world of consciousness)". Tiap-tiapnya merepresentasikan jenis proses sebagai model pengalaman pembicara/penulis baik dari dalam diri sendiri (kesadaran diri dan imajinasi) atau dengan orang dan alam sekitarnya Jenis proses yang mencakup pengalaman dalam diri sendiri adalah proses MENTAL meliputi "seeing”, 'feeling”, dan "thinking". Contoh: M1.Q2.

If feel (Mental process: Perception) a heavy and sudden beat and a feeling as i fI had been frightened.

DIKSI Vol.12, No.2, Juli 2005 
Pengalaman berkaitan dengan orang dan alam sekitarnya dapat berbentuk tindakan dan kejadian, misalnya terjadi sesuatu, orang-orang atau pelaku ("actor") lain, melakukan sesuatu, atau membuat sesuatu terjadi. Proses demikian ini disebut proses MATERIAL. Contoh: M7.Q3.

My doctor gave (Material process) me somethingfor acid, but it didn't help.

Di antara proses material dan proses mental adalah proses BEHAVIOURAL, yang didefinisikan oleh Halliday (1994:107) sebagai "those that represent outer manifestations of inner workings, the acting out of processes of consciousness and physiological states". Pengalaman dari dalam diri sendiri agak sulit dibedakan. Untuk ini Matthiessen (1996) berupaya memberikan paparan rinci tentang proses BEHAVIOURAL dengan membaginya dalam intro-aktif (perseptif, kognitif, afektif, para-verbal, dan menangis, bemafas, berdesah, batuk, etc.) dan interaktif (verbal dan hal lain: menari, berkelahi, memeluk, mencium, d11). Contoh:

M5.A15.

Although I cannot diagnose (Behavioural process) your basic problem, I believe I can explain it and perhaps (I) offer some suggestions [[to improve the situation]] .

Ketika seseorang menggeneralisasikan, misalnya untuk menghubungkan sepenggal pengalaman ke hal lain: ini sama dengan itu, ini bagian dan yang lain, dapat dikategorikan sebagai mengklasifikasi dan mengidentifikasi.Proses demikian disebut proses RELATIONAL (Halliday 1994:107). Contoh:

P4.A8.

They can examine you tell you if you are (Relational Attributive process) really pregnant and help you decide what to do.

M3.A10.

Sometimes changing footgear, equipment or terrain seems (Relation Identifying process) to be related to their onset.

M5.A39.

Your kidneys think you have (Relational Possessive process) too much fluid in your arteries. 
Ketika seseorang mengangankan suatu hubungan simbolik dalam alam kesadarannya dan mewujudkannya dalam bentuk bahasa, seperti berujar dan memaknainya, kegiatan demikian dikategorikan sebagai proses VERBAL. Proses ini berada di antara proses MENTAL dan proses RELATIONAL. Contoh:

P 1. .Q3a.

He is begging (Verbal process) me to forgive him, and he claims (Verbal process) they did everything but sex.

Selain di atas, terdapat proses di antara proses RELATIONAL dan proses MATERIAL, disebut proses EXISTENTIAL. Proses ini berkaitan dengan keberadaan sesuatu, "by which all phenomena of all kinds are simply recognized to 'be' to exist or to happen." (ibid) (lihat juga Davidse 1992). Contoh:

M3.A4a.

OK, OK, they HURT! and there is (Existential process) no doubt [[that they are a potentially debilitating problem]]

Kesemua proses di atas oleh Matthiessen (1995:207) dideskripsikan secara rinci pada Gambar 2: Agency, process type and dependency systems (Lihat Lampiran I).

“Clause as exchange” berkaitan dengan peran interlokutor (pembicara dan pendengar) dalam memberi dan meminta informasi selama proses transaksi dan negosiasi berbagai hal. Dari sini terjadi interaksi yang mengimplikasikan adanya pertukaran respon. Pertukaran ini mewujudkan empat fungsi primer berbicara yaitu OFFER, COMMAND, STATEMENT dan QUESTION yang dikaitkan dengan respon yang dikehendaki (Halliday 1994:68-69) dipaparkan pada Tabel 2: Speech functions and responses.

Pertukaran informasi ini mungkin dalam bentuk proposisi atau proposal (ibid:70-71). Bahasa yang dipakai untuk saling bertukar informasi membuat pembentukan klausa berupa proposisi. Yang dimaksudkan proposisi adalah sesuatu yang dapat diperdebatkan,

DIKSI Vol.12, No.2, Juli 2005 
ditegaskan, disangkal, diragukan, dipertentangkan, dituntut, diterima dengan syarat, dsb.

Tabel 2: Speech functions and responses (Halliday 1994)

\begin{tabular}{|c|c|c|c|c|c|}
\hline & & initiation & expected response & $\begin{array}{l}\text { discretionary } \\
\text { alternative }\end{array}$ & \\
\hline $\begin{array}{l}\text { give } \\
\text { demand } \\
\text { give } \\
\text { demand }\end{array}$ & $\begin{array}{l}\text { good-\&-services } \\
\text { good-\&-services } \\
\text { information } \\
\text { information }\end{array}$ & $\begin{array}{l}\text { offer } \\
\text { command } \\
\text { statement } \\
\text { question }\end{array}$ & $\begin{array}{l}\text { acceptance } \\
\text { undertaking } \\
\text { acknowledgement } \\
\text { answer }\end{array}$ & \begin{tabular}{|l|} 
rejection \\
refusal \\
contradiction \\
disclaimer
\end{tabular} & $\begin{array}{l}\text { PROPOSAL } \\
\text { PROPOSITION }\end{array}$ \\
\hline
\end{tabular}

PROPOSITION ini dalam fungsi semantik berwujud STATEMENT dan QUESTION, sedangkan PROPOSAL dalam "Good-\&-services" berupa OFFER dan COMMAND, yang tidak dapat disangkal.

Jika membahas "clause as exchange" yang perlu diamati adalah bentuk proposisi karena gramatikanya dapat dengan jelas diamati. Secara gramatika "clause as exchange" ini dikelola oleh sistem MOOD. MOOD terdiri atas dua bagian: Subject dan "finite operator" (finite verbal operators: temporal operators dan modal operators). Bagian setelah Mood dari suatu klausa disebut RESIDUE [Predicator, Complement, dan Adjunct (Modal Adjunct terdiri atas Mood dan Comment Adjunct)]. Contoh ${ }^{10}$ MOOD di mana 'gave' menyatu sebagai Finite dan Predicator:

M7.Q3a.

My doctor (Subject) gave (Finite:Past tense)(Predicator) me somethingfor acid Mood Residue

Berkaitan dengan Predicator, hal yang patut dicatat adalah ia mempunyai empat fungsi: i) merujuk pada penanda kala; i) merujuk berbagai 'aspects' dan 'phases' seperti seeming, trying, hoping, iii) merujuk "voice" aktif atau pasif; dan iv) merujuk pada jenis proses (tindakan, kejadian, mental, relasi) yang melekat pada Predicator dari suatu Subject (Halliday 1994:79).

Piranti Komputasional Systemic Coder (Pangesti Wiedarti) 
Berkaitan dengan "clause as exchange", karakteristik kategori gramatika yang digunakan dapat dilihat pada Gambar 3: Mood systems (plus clausal ellipsis) (Matthiessen 1995).

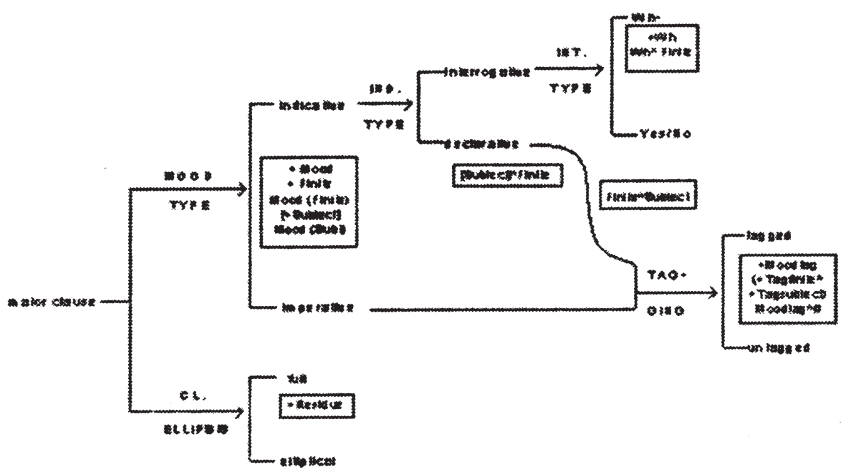

Gambar 3: Mood systems (plus clausal ellipsis) (Matthiessen 1996)

Negosiasi antar interlokutor dalam "clause as exchange" ini bersifat terbuka. Maksudnya, interlokutor dapat memasukkan berbagai perilaku interpersonal dan komentar, memperkirakan kekuatan PROPOSITION atau PROPOSAL itu sendiri atau mengkhususkan pada nilai-nilai fungsi wicara (Matthiessen 1996). Dalam hal ini, sistem "modality" dapat digunakan untuk menunjang kegiatan bernegosiasi.

Teori "modality" dengan berbagai pendekatan banyak dikembangkan oleh para linguis antara lain: Perkins (1983), Coates (1990, 1995) dan Palmer (1995). Makalah ini merujuk sistem "modality” yang dikembangkan Matthiessen (lihat Lampiran II, Gambar 4: Basic system of modality (Matthiessen 1996) dan Lampiran III, Tabel 3: Examples of items at intersection of modality system) karena makalah ini hams konsisten dengan tradisi genre 'Sydney School'yang menggunakan SFL sebagai alat menganalisis bahasa.

Hal yang perlu mendapat perhatian dalam pemakaian sistem Modality pada kerangka SFG adalah tidak adanya penanda kala karena SFL menempatkan kala dalam kelompok verbal (kata kerja) yang istilah gramatikalnya dinamai primary tense (Halliday 1994). Contoh:

DIKSI Vol.12, No.2, Juli 2005 
P1.A1

These are some questions that you can ask yourself: What are the qualities of your husband/marriage that you value?

can -> Modalisation: Probability; Low; Subjective; ask <-> primary tense Statement -> Proposition

“Clause as message” berkaitan dengan pengorganisasian pengembangan informasi dalam suatu klausa, dan dari sini menuju teks yang lebih besar; dibahas dalam "textual metafunction" (Martin, Matthiessen Painter 1997:21). Setiap pesan yang disampaikan dalam suatu klausa diorganisasikan oleh sistem THEME yang terdiri atas dua bagian, yaitu "Theme" dan "Rheme", yang masing-masing mempunyai fungsinya. Theme didefinisikan sebagai suatu konteks lokal atau titik tolak pembicara ketika dia memulai menyampaikan pesannya. Karena munculnya pada bagian awal, ia berfungsi sebagai latar belakang informasi yang disampaikan dan karenanya dinamai "Given" . Bagian yang mengikuti "Theme" disebut "Rheme" yang berisi pesan itu sendiri, yang diasumsikan berisi sesuatu yang perlu diketahui oleh penerima pesan. Menurut Halliday (1994) kehadiran "New” merupakan hal wajib dan "Given” bersifat manasuka. Contoh:

P1.A12

You may also be having difficulty living next door to your neighbour

Given New

The thing about being hurt and angry with your partner is that you create emotional distance Given New

and sometimes it can feel like a "wall" between you

Given

New

Pemilihan MOOD oleh interlokutor mempengaruhi unsur Theme dalam klausa declarative, interrogative, atau imperative. Dalam klausa declarative, ketika suatu Subject merupakan Theme, dinamai 
UNMARKED THEME. Contoh

M5.Q 1

I feel almost desperate.

Unmarked Theme Rheme

Jika unsur terpilih sebagai Theme adalah selain Subject, disebut MARKED THEME. Contoh:

M1 .Q9b

and for the past 2 years I only experienced maybe less than ten very minor occurrences

Textual theme Marked Theme Rheme

Halliday, (1994:44) menyatakan bahwa bentuk umum dari MARKED THEME adalah kelompok adverbial, dan yang paling sedikit adalah "complement". Martin \& Rose (2003) menambahkan "marked Themes are often used to signal new phases in a discourse a new setting in time, or a shift in major participants; that is they function to scaffold discontinuity".

Dalam klausa exclamative yang tipikal, WH-element berfungsi sebagai Theme (Halliday, 1994:45). Dalam klausa interrogative Yes/ No unsur Theme adalah finite verbal operator yang mengekspresikan positif atau negatif, dan dalam WH-question, Wh-element berfungsi sebagai Theme karena berfungsi mendapatkan informasi yang diinginkan. Dalam klausa imperative, predicator (kata kerja) secara teratur berfungsi sebagai Theme.

Analisis Theme menghasilkannya alur pengembangan informasi dalam suatu teks ${ }^{13}$, yang oleh Halliday \& Pike (Martin \& Rose 2003) disebut "waves". Keteraturan alur pengembangan informasi ini cenderung membentuk suatu pola dan disebut "periodicity”. Berdasarkan periodicity, hirarki "waves" dapat diprediksi oleh petnbaca.

Analisis bahasa berbasis SFG akin menghasilkan karakteristik suatu teks yang berbeda satu dan yang lainnya dan karakteristik ini jika diteliti secara ajeg akan menghasilkan pola teks bersangkutan. Misalnya,

DIKSI Vol.12, No.2, Juli 2005 
Wiedarti (2004) yang membandingkan karakteristik dua jenis teks advice column medis dan psikologi menemukan perbedaan signifikan dalam ketiga metafunction dan beberapa aspek dalam speech functions (terlebih lagi jika dianalisis dari dimensi Appraisal System perbedaaan akan semakin tampak jelas).

Hasil analisis karakteristik teks berbasis SFG (dipadu dengan analisis genre) akan bermanfaat bagi model pembelajaran baca-tulis teks (lihat Wiratno, 2003; dan lihat juga KBK Bahasa Inggris untuk SLTP dan SMA yang mengarah ke penggunaan SFG, yang sementara ini penekanannya diberikan ke genre dulu).

\section{Systemic Coder}

SC 4.63 (http://www.wagsoft.com/software.html, Februari 2002) merupakan piranti komputasional yang berfungsi membantu penganalisisan korpus data berupa teks. SC terus-menerus dikembangkan agar lebih mudah digunakan. Karena SC adalah mesin (yang padahal dalam menganalisis bahasa diperlukan sense khusus), konsekuensinya, tingkat akurasi hasil analisis tidak dapat mencapai 100\%. Tingkat akurasi ini dipengaruhi karakteristik teks dari sisi isi/keilmuan. Misalnya, dalam bidang kedokteran, hambatan terletak pada istilah teknis/jargon. Selain itu, semakin panjang suatu kalimat, misalnya terdiri dari 23 kata, akan membuat tingkat akurasi menurun, dan parsing memakan waktu lebih lama (p.c. O'Donnell via email 15 September 2004). Walaupun begitu SC akan tetap bermanfaat dalam mengurangi beban kerja peneliti terutama jika data sangat besar dengan tujuan memperoleh gambaran secara cepat mengenai kecenderungan jenis teks berdasarkan hasil analisis kuantitatifteks.

O'Donnel dalam presentasinya tentang "Machine Learning Techniques to the Coder" di Liverpool pada tahun 2002 menegaskan bahwa mesin hanyalah alat bantu yang mempercepat proses analisis, sedangkan peran peneliti untuk mengoreksi kesalahan masih diperlukan.

Dengan kata lain, penganalisisan data dengan mesin tidak pernah menghilangkan peran manusia. 
Berikut ini dipaparkan secara ringkas bagaimana SC diterapkan. Langkah-langkah penerapan SC mencakup: a) Text Segmentation, b) Scheme Management, c) Coding, d) Review, dan e) Statistics.

a) Text Segmentation: untuk menandai batas di antara bagian teks

1. Teks yang akan dianalisis dapat berupa teks dalam platform MSWord atau WorPerfect. Beri tanda double (misalnya ][][ ) pada awal setiap paragraf sebagai penanda paragraf baru dalam teks tsb.

2. Teks tersebut harus di-save dalam bentuk PLAIN TEXT dengan cara "Save as Text"

3. Launch Coder 4.63, terdapat IMPORT TEXT FILE, LOAD CODINGS, QUIT. Import Text File dilakukan jika teks yang akan dianalisis merupakan teks baru; Load Coding dilakukan jika teks sudah di-coding. Maksudnya, jika suatu saat Import Text File setelah di-coding dan di-save, akan dapat dibuka lagi dalam mode Load Coding.

Lihat Gambar Cl, Text File - Locate, diisi dengan teks yang akan di-coding. Untuk Encoding, pilih Standard.

SCHEME: Scheme adalah acuan yang dipakai untuk kisikisi menganalisis data. Scheme ini dibuat sesuai dengan tujuan analisis pada aspek karakteristik mana bahasa akan dianalisis aspek leksikogramatikanya. Jika Scheme dibuat dari awal, pilih "Start from Scratch". Jika sudah dibuat sebelumnya, bisa dipilih Use Master: (jika Scheme di-save terpisah dari dari Coding File) atau Copy from (jika coding scheme terpadu pada file yang telah di-coding sebelumnya). Lalu tekan Import. 


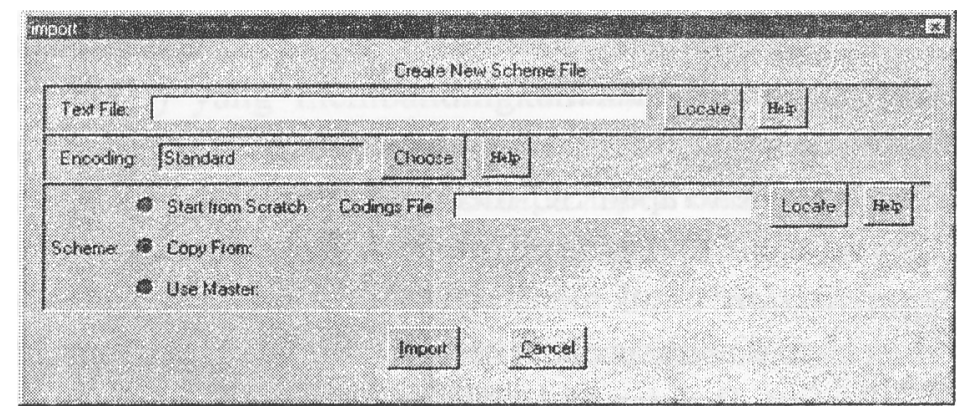

Gambar Cl: The Import Dialog

Setelah Import ditekan, akan muncul Gambar C2 sebagai berikut.

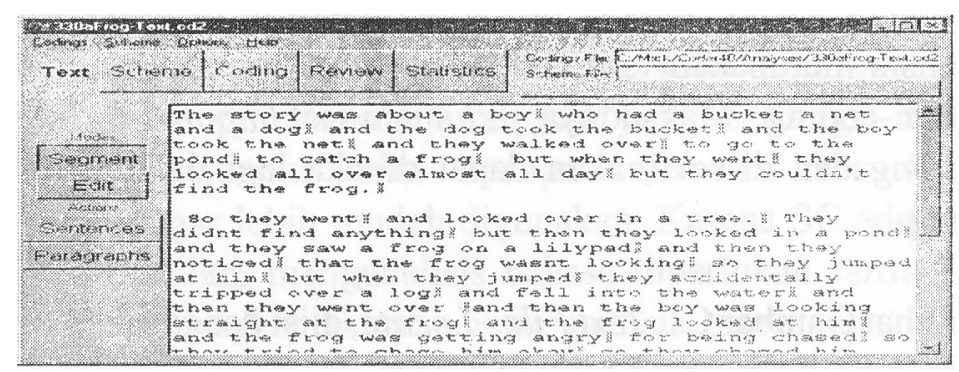

Gambar C2: The Text Segmentation Interface

Teks yang berupa wacana ini, terbagi atas paragraf, dan kemudian dipilah dengan tanda ][ pada kalimat-kalimat (dapat dilakukan secara otomatis), berikutnya pemilahan pada klausa (ingat dalam SFG, text is like a clause, klausa merupakan objek analisis) dilakukan secara manual. Pemilahan ini dapat dilakukan dengan cara a) Segment Mode: tiap klik pada teks akan menghasilkan pemilahan baru pada titik yang diklik. Jika sudah terdapat ][ pada titik tersebut, pemberian ][ baru akan membuat ] [ lama terhapus; dan b) Edit Mode: teks dapat diedit sebagaimana jika mengedit teks dalam edit window. Tapi penanda ][ tidak dapat dihapus dengan backspace keys. Setelah itu lakukan save as a Codingsfile, dan harus diyakinkan pilih (*cd2), misalnya nama file akan menjadi: Med-1 -Q.cd2. 


\section{b) Scheme Management}

Kembali ke SCHEME yang telah disinggung sebelumnya, pada langkah berikutnya, klik Menu: SCHEME, akan muncul file [tapi kini dengan $\left({ }^{*} \operatorname{cd} 3\right)->$ Med-1-Q.cd3].

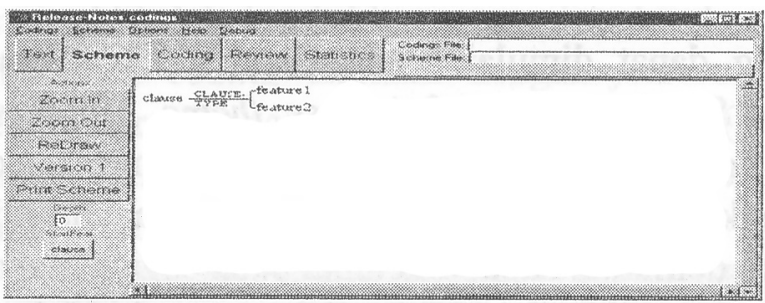

Gambar C3: The Scheme Interface with a new scheme

Scheme dapat dikreasikan dengan langsung klik pada feature, dan feature dapat dibuat sesuai keperluan analisis data. Misalnya kreasi Scheme sederhana seperti berikut.

\section{Mood Network}

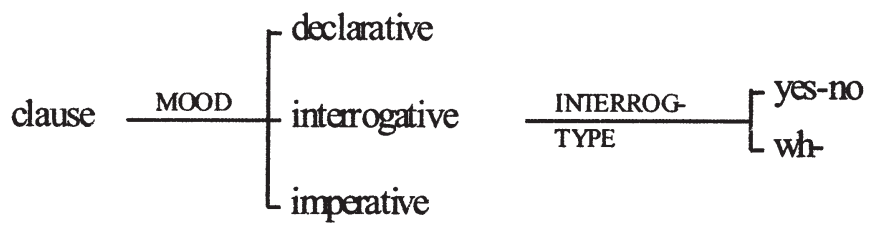

Atau dibuat Scheme yang lebih kompleks seperti pada Gambar C4 sebagai berikut

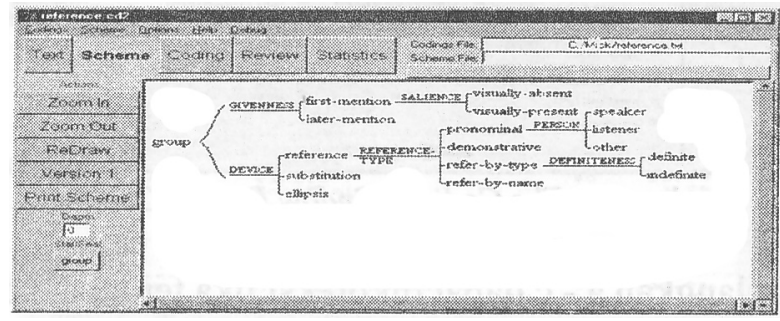

Gambar 4: A more complex scheme

DIKSI Vol.12, No.2, Juli 2005 
Setelah Scheme dibuat, save Scheme. Scheme ini akan terpadu dengan teks yang telah dipilah-pilah. Artinya, ketika Load Codings dan dipilih teks Med-1-Q, berikutnya klik Menu pada Scheme, akan muncul Scheme yang dibuat di atas. Scheme ini dapat digunakan untuk analisis teks lain jika dilakukan analisis dengan Scheme yang sama. Dalam hal ini, klik Menu Scheme: Copy Scheme From.

\section{c) Coding}

Coding dapat dimulai. Pada Gambar C6, Network System memunculkan Scheme dengan finiteness, theme, progression, aspect, process type, polarity. Klausa yang dianalisis ditampilkan dalam warna merah, sedangkan klausa yang telah dan akan dianalisis dalam warna hitam. Dengan demikian dapat diketahui pada bagian mana yang telah, sedang, dan akan dianalisis. Analisis manual dilakukan dengan mengklik button (butang) yang dipilih sesuai analisis terhadap korpus. Ada kalanya korpus diabaikan saja (tentu dengan alasan sang peneliti) maka diberikan Ignored button. Komentar terhadap analisis juga dapat diberikan kalau misalnya ada keraguan terhadap penganalisisan korpus data. Hasil coding ini tidak secara otomatis di-save ke disk. Coding yang komplit tersimpan dalam memori sampai pada akhirnya dilakukan "Save" dari Menu "Codings".

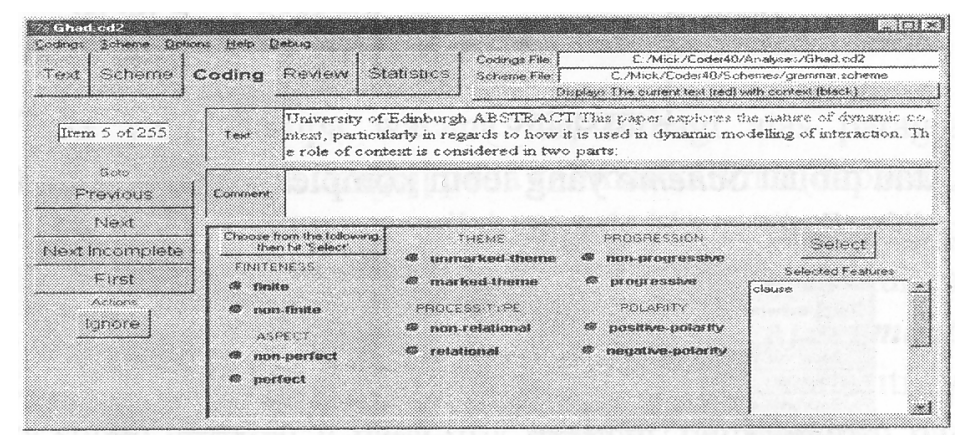

Gambar C6: The Coding Window During Coding

Semua langkah a - c dapat dikoreksi jika terdapat keraguan atau kesalahan. 


\section{d) Corpus Review}

Seberapa coding dilakukan dapat diketahui, seperti tampak dalam Gambar C7, tiap klausa disajikan pada tiap bans. Tanda "C" di depan setiap klausa menunjukkan coding telah komplit, sedangkan tanda "I" berarti Ignored, penanda bagi klausa yang diabaikan peneliti ("I" tidak akan masuk dalam analisis statistik). Untuk mengoreksi, dapat dilakukan dengan klik dobel pada klausa yang dimaksud.

Semua hasil coding terekam dengan feature tertentu atau kombinasi feature tersebut dan dapat di-save "As Text" (hanya teks dan codingnya) atau "Detailed Text" (selain hasil rinci coding juga terekam komentar peneliti terhadap korpus itu).

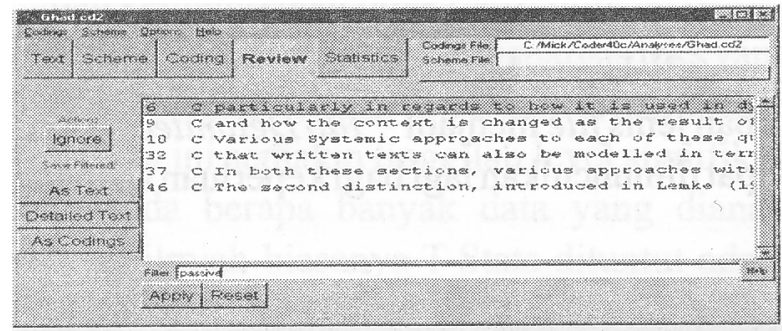

Gambar C7: The Review Interface

\section{e) Statistics}

Hasil analisis statistik yang ditampilkan SC adalah statistik deskriptif (hasil means, dll., setiap feature; lihat Gambar C8a), dan statistik komparatif (memilah coding menjadi dua atau tiga set dan hasil analisis menunjukkan perbedaan signifikan kedua set ini, lihat Gambar $\mathrm{C} 8 \mathrm{~b})$.

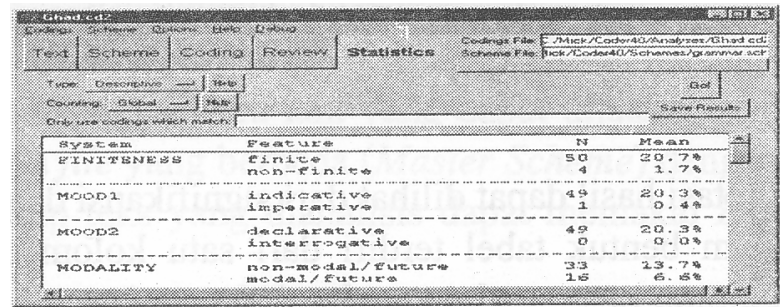

Gambar C8a: Descriptive Statistics

DIKSI Vol.12, No.2, Juli 2005 
Mean yang ditampilkan dapat berapa Global Mean dan Local Mean. Global Mean menampilkan kemungkinan pemilihan korpus secara keseluruhan dengan cara membagi jumlah feature yang muncul dalam coding dengan jumlah keseluruhan coding yang dilakukan. Local Mean menampilkan kemungkinan pemilihan dalam suatu sistem dengan cara membagi keseluruhan jumlah coding berdasarkan feature ini dengan jumlah coding yang dipilih dalam sistem yang sama. Karenanya, jumlah total dalam semua feature dalam sistem ini selalu $100 \%$.

Untuk memilih Descriptive atau Comparative, Global atau Local, tinggal meng-klik pada box bersangkutan dan Go! Untuk menyimpan hasil analisis statistik ini, tekan Save Results untuk menghasilkan plain text, atau dapat dipilih HTML file. Agar hasil statistik ini dapat diekspor, lakukan "Save Codings As ..." dari Menu Codings dan ubah jenis file menjadi "Tab Delimited". Dengan demikian file ini akan dapat dimunculkan lagi bagi keperluan analisis statistik yang lebih rinci.

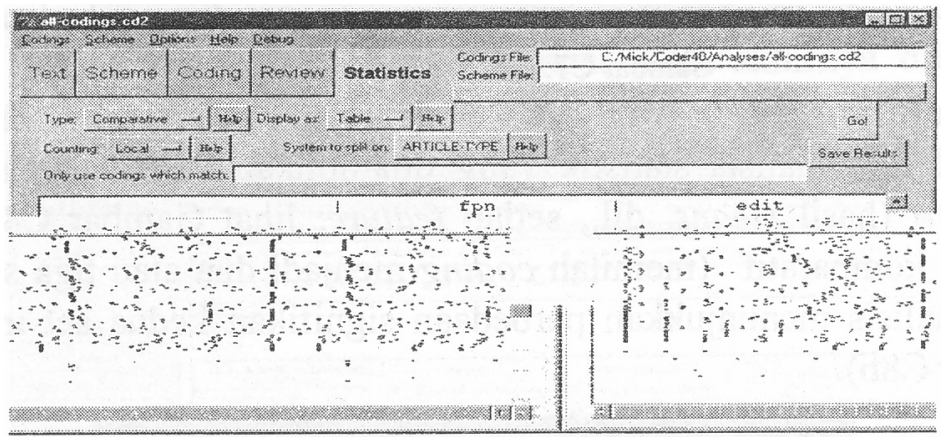

Gambar C8b: The Comparative Statistics Display

Interpretasi hasil dapat dilihat dari signifikansi dan T-statistics. Presentasi dalam bentuk tabel terdiri dari satu kolom untuk setiap feature, menghitung pemunculannya dan informasi tentang perbedaan hasil satu feature dan feature lainnya. Perbedaan di antara mean ditunjukkan dengan indikator:

Piranti Komputasional Systemic Coder (Pangesti Wiedarti) 
(i) Level of Significance: pada akhir tiap "entry" terdapat 0 - 3 tanda "+". Tanda ini menunjukkan secara signifikan perbedaaan mean feature dari mean keseluruhan data yang dianalisis:

(none) Not significantly different.

+ Significant at the $90 \%$ level (10\% chance of error).

++ Significant at the $95 \%$ level (5\% chance of error).

+++ Significant at the $98 \%$ level (2\% chance of error).

Level signifikansi ini penting untuk menentukan hasil analisis dapat dipakai lagi atau tidak. Hasil tanpa signifikansi bisa jadi karena "kecelakaan", dan kemungkinan tidak dapat diulang pada teks lain. Jika tinggi signifikansinya, dapat dipakai menganalisis teks yang berbeda.

(ii) T-Statistic: T-Stats adalah angka di mana level signifikansi diperoleh. Semakin besar angka ini semakin tinggilah level signifikansi. Tetapi ini juga tergantung pada berapa banyak data yang dianalisis. Untuk keperluan makalah ilmiah biasanya T-Stats dituntut ada, tetapi hal ini jarang dilakukan dalam bidang linguistik.

Paparan System-By-System juga menunjukkan standar deviasi tiap mean. Statistik ini menunjukkan berapa banyak variasi dalam data. Lebih rincinya dapat dilihat pada http://www.robertniles.com/stats/stdev. shtml).

Untuk meng-coding dua teks dengan menggunakan network yang sama, dan kemudian membandingkan bagaimana perbedaan keduanya dalam menggunakan system. Dalam hal ini harus: 1) Diyakini bahwa dua teks ini menggunakan coding yang sama. Setiap file teks yang di-coding harus terpadu dengan Scheme pada file tersebut. Coding dan Scheme menjadi satu. Cara lain yang dapat dilakukan adalah Scheme disimpan pada file yang berbeda (Master Scheme) dengan file yang di-coding. Setiap teks yang dianalisis dapat memakai External Master Scheme

Cara mengubah file yang terpadu dengan Scheme ke penggunaan External Master Scheme adalah: a) Buka file yang di-coding. b) Pada Menu Options, pilih Save Options ... c) Pada sajian window, pilih Save to Master. d) Kemudian tekan butang Locate pada window, dan ketik nama file bagi New Master Scheme. Tekan pada butang OK untuk kembali ke

DIKSI Vol.12, No.2, Juli 2005 
window sebelumnya, dan tekan Done.

File yang di-coding itu kini memerlukan Master Scheme jika digunakan. Jika mengimpor teks untuk memulai peng-coding-an berikutnya, pilih "Start from Scratch" yang berarti mulai dari awal. Tapi kali ini dengan menggunakan Scheme "Use Master", atau pilih Master Scheme yang baru. Berikutnya dilakukan pemilihan terhadap teks dengan Scheme yang sudah tersedia. Setelah pemilahan, coding dilakukan terhadap teks lain, dst. dapat dilakukan; dan save teks-teks tersebut. Jika ingin mengubah network selama peng-coding-an, file pertama dibuka lagi, lalu perbarui coding untuk meyakinkan bahwa pengubahan network dapat berjalan baik bagi file tersebut. Pada bagian Coding, gerakkan ke coding pertama dan tekan "Next Incomplete" untuk melihat jika ada yang perlu ditambahkan. 2) Buka salah satu dari file yang ada dalam Coder. 3) Beralih ke Statistics dan pilih Compare Files dari Menu Descriptive. 4) Item bare muncul di layar, menanyakan nama file untuk dibandingkan, klik butang Locate dan pilih file lain yang menggunakan Scheme sama. 5) Klik butang Go, dan hasil analisis statistik akan segera diperoleh.

Selain di atas terdapat Cell Analysis yang sangat bermanfaat untuk mengindentifikasi pola korpus dari semua coding yang mempunyai feature sama. Pilih "Cell Analysis" Menu "Type:" dan tekan butang "Go". Paparan akan menunjukan setiap kelompok sesuai ukuran. Untuk setiap kelompok, ditunjukkan feature umum kelompok dan sebuah contoh, jumlah coding dalam kelompok dan anggota kelompok. Untuk mengurangi jumlah coding dalam kelompok yang digunakan oleh kelompok cell, tekan "Ignore systems" dalam Scheme window. Buang systems yang rumit, atau mungkin tidak relevan untuk pengelompokan.

\section{Kesimpulan}

SC 4.63 merupakan alat bantu analisis bahasa berbasis SFG. Untuk menerapkannya diperlukan penguasaan tentang SFG terlebih dahulu terutama karena penerapan SC tidak sepenuhnya otomatis. 
Hal ini disebabkan oleh adanya pertimbangan akan rasa bahasa dalam menganalisis bahasa masih diperlukan. SC dalam hal ini dapat membantu peneliti untuk mendapatkan informasi secara cepat tentang kecenderungan karakteristik teks yang dianalisis. Kebermanfaatan SC dapat diketahui melalui pelatihan dengan jumlah peserta terbatas. Pelatihan dapat dimulai dengan analisis data bahasa yang sama, berikutnya dapat dilakukan dengan data dan beberapa bahasa yang dikuasai peserta, misalnya bahasa Jawa, bahasa Indonesia, bahasa Jerman, bahasa Perancis, dan lain-lain.

\section{DAFTAR. PUSTAKA}

Berry, M. 1995. "Thematic options and success in writing" dalam Ghadessy, Mohsen (Ed) Thematic development and its relationship to registers and genres. London and New York: Pinter, 55-84.

Berry. M. 1996. "What is theme?_a(nother) personal view" dalam Berry, Margaret; Butler, Christopher; Fawcett, Robin P; Huang, Guowen (Ed) Meaning and form: systemic functional interpretations. Meaning and choice in language: studies for Michael Halliday. Volume LVII in the series Advances in discourse processes. Norwood, New Jersey: Ablex Publishing Company, 1-64.

Bowers, F. 1988. "The thematization of propositional arguments" dalam Benson, James and Greaves, William Systemic functional approaches to discourse. Selected papers from The 12th International Systemic Workshop. Norwood, New Jersey: Ablex Publishing Corporation, 271-281.

Callaghan, M. \& Rothery, J. 1993. Teaching factual writing. A genrebased approach. Erskineville, NSW, Australia: Metropolitan East Disadvantaged Schools Program.

Coates, J. 1990. "Modal meaning: the semantic-pragmatic interface". Journal of Semantics, Vol 7 (1): 53-63.

. 1995. "The expression of root and epistemic possibility in English” dalam Bybee, Joan and Suzanne Fleischman (Eds)

DIKSI Vol.12, No.2, Juli 2005 
Modality in grammar and discourse. Amsterdam/Philadelphia: John Benjamins Publishing Company, 55-66.

Cummings, M. 1994. "Structural semantics as the basis for theme/rheme" The 21 LACUS FORUM 1994: 443-459.

Downing, A. 1991. "An alternative approach to theme: a systemic functional perspective" WORD 42(2): 119-144.

Eiler, M. Ann. 1986. "Thematic distribution as a heuristic for written discourse function" dalam Couture, Barbara Functional approaches to writing. Research perspectives. London: Frances Pinter (Publisher):

Firbas, J. 1995. "A contribution on a panel discussion on rheme" dalam Ghadessy, Mohsen (ed) Thematic development and its relationship to registers and genres. London and New York: Pinter, 213-222

Francis, G. 1989. "Thematic selection and distribution in written discourse" WORD 1989, 40, 1-2, Apr-Aug: 201-221.

Fries, P. H. 1983. "On the status of theme in English: argument from discourse" dalam Petofi, Janos S. \& Emel Sozer (Eds.). 1983. Micro and macro connexity of texts. Hamburg: Helmut Buske Verlag

. 1995a. "On theme, rheme and discourse goals" dalam Coulthard, Malcolm Advances in written text analysis. London \& New York: Routledge:229-249.

. 1995b. "Patterns of information in initial position in English" dalam Fries, Peter H and Gregory, Michael (Eds). Discourse in society: systemic functional perspectives. Meaning and choice in language: Studies for Michael Halliday Volume L. New Jersey: Ablex Publishing Corporation: 47-66.

. 1995c. "Themes, Methods of development, and texts" dalam Hasan, Ruqaiya \& Fries, Peter H (Eds) On subject and theme. Current issues in linguistic theory 118. Amsterdam/Philadelphia: John Benjamins Publishing Company: 
. 1995d. "A personal view of theme" dalam Ghadessy, Mohsen (Ed) Thematic development and its relationship to registers and genres. London and New York: Pinter, 1-19.

Ghadessy, M. 1995. "Thematic development and its relationship to registers and genres" dalam Ghadessy, Mohsen (Ed) Thematic development and its relationship to registers and genres. London and New York: Pinter, 129-146.

Halliday, M.A.K. 1978. Language as social semiotic, the social interpretation of language and meaning. London: Edward Arnold.

. 1985. Introduction to Functional Grammar 1st Edition. London, New York, Sydney, Auckland: Arnold.

. (1982). How is a text like a clause?. Text analysis and generation, text typology and attribution (Proceedings of Nobel Symposium Vol. 51) (pp. 209-247). Stockholm-Sweden: Almqvist and Wiksell International. .1994. Introduction to Functional Grammar 2nd Edition. London, New York, Sydney, Auckland: Arnold.

Halliday, M.A.K \& Matthiessen, Christian. 2003. Introduction to Functional Grammar 3rd Edition. Oxford: Oxford University Press.

Hartnett, C. 1995. "The pit after the theme" dalam Ghadessy, Mohsen (Ed) Thematic development and its relationship to registers and genres. London \& New York: Pinter, 198-212.

Hasan, R. and Fries, P.H. 1995. "Reflection on subject and theme: an introduction" dalam Hasan, Ruqaiya \& Peter H Fries (Eds) On subject and theme. A discourse functional perspective. Amsterdam/Philadelphia: John Benjamin Publishing Company, xiii-xliv.

Huang, G. 1996. "Experiential enhanced theme in English", Meaning and form: systemic functional interpretations. Meaning and choice in language: studies for Michael Halliday. Volume LVII in the

DIKSI Vol.12, No.2, Juli 2005 
series Advances in discourse processes. Norwood, New Jersey: Ablex Publishing Company, 65-112.

Kies, D. 1988. "Marked themes with and without pronominal reinforcement: their meaning and distribution in discourse" dalam Steiner, Erich H \& Robert Veltman (Eds) Pragmatics, discourse and text Vol. II Advances in discourse processes. Norwood, New Jersey: Ablex Publishing Corporation, 47-75.

Macquarie Systemic Modelling Group (http://minerva.ling.mq.edu.au/ Resource/AnalysisTools/tools.htm)

Martin, J.R. 1992. English Text: System and Structure. Philadelphia/ Amsterdam: John Benjamins Publishing Company. .1995. "More than what the message is about: English theme" dalam Ghadessy, Mohsen (Ed) Thematic development and its relationship to registers and genres. London and New York: Pinter, 223-258.

. 1996. "Metalinguistic diversity: the case from case" dalam Cloran, Carmel; Butt, David \& Hasan, Ruciaiya (Eds) Functional descriptions: theory into practice, pages 323-375. Benjamins, Amsterdam, 1996.

Martin, J.R., Matthiessen, C.M.I.M. \& Painter, C. 1997. Working with Functional Grammar. Oxford: OUP.

Martin, J.R. \& Rose, D. (2003) Working With Discourse: Meaning Beyond the Clause. New York \& London: Continuum Intl Pub Group.

Matthiessen, C.M.I.M. 1995. "THEME as enabling resource in ideational 'knowledge' construction" dalam Ghadessy, Mohsen (Ed) Thematic development and its relationship to registers and genres. London and New York: Pinter, 20-54. 1996. Lexicogrammatical cartography: English systems. Tokyo, Taipei and Dallas: International Language Science Publisher.

Nwogy, K. and Bloor, T. 1991. "Thematic progression in professional and popular medical texts" dalam Ventola, Eija. Functional and systemic Linguistics: Approaches and uses. Berlin: Mouton de 
Gruyter: 369-384.

O’Donnell, Mick. (http://www.wagsoft.com/software.html)

Palmer, F.R. 1995. "Negation and the modals of possibility and necessity" dan Bybee, Joan and Suzanne Fleischman (Eds) Modality in grammar and discourse. Amsterdam/ Philadelphia: John Benjamins Publishing Company, 453-471.

Perkins, M. R. 1983. Modal Expression in English. London: Frances Pinter (Publishers).

Pusat Kurikulum Balitbang Departemen Pendidikan Nasional Republik Indonesia (http://www.puskur.or.id)

Ravelli, L.J. 1995. "A dynamic perspective: implications for metafunctional interaction and an understanding of theme" dan Hasan, Ruciaiya \& Peter H Fries (Eds) On subject and theme. A discourse functional perspective. Amsterdam/Philadelphia: John Benjamin Publishing Company, 187-234.

Summer Insitute of Linguistics (http:/www.sil.org/computing/catalog/ showsoftware_catalog. asp?by=all\&name $=$ )

Sutjaja, M. 1989. "Perkembangan Teori Bahasa M.A.K. Halliday" makalah disajikan dalam PELLBA III UnikaAtmajaya Jakarta. Whittaker, R. 1995. "Theme, process and realization of meanings in academic articles" dalam Ghadessy, Mohsen (Ed) Thematic development and its relationship to registers and genres. London and New York: Pinter, 105-146.

Wiedarti, P. 2004. Supportive genres: the language of advice columns Volume 2. Data (thesis Ph.D, Linguistics Department, the University of Sydney, NSW, Australia).

Wiratno, T. 2003. Kiat Menulis Karya Ilmiah dalam Bahasa Inggris. Yogyakarta: Pustaka Pelajar.

DIKSI Vol.12, No.2, Juli 2005 